\title{
Kalite Bağlamında Sağlık Personeli Eğitimi
}

\author{
Health Personnel Education In Quality Context
}

\author{
Selma Altındiş, Aysun Ergin \\ Sakarya Üniversitesi, İ̧letme Fakültesi, Sağlık Yönetimi A.D., SAKARYA \\ Yazışma Adresi / Correspondence: \\ Selma Altındiş \\ Sakarya Üniversitesi, İşletme Fakültesi, Sağlkk Yönetimi AD. Sakarya \\ T: $+905326615263 \quad$ E-mail: altindis@sakarya.edu.tr
}

Geliş Tarihi / Received : 16.02.2018 Kabul Tarihi / Accepted : 04.03.2018

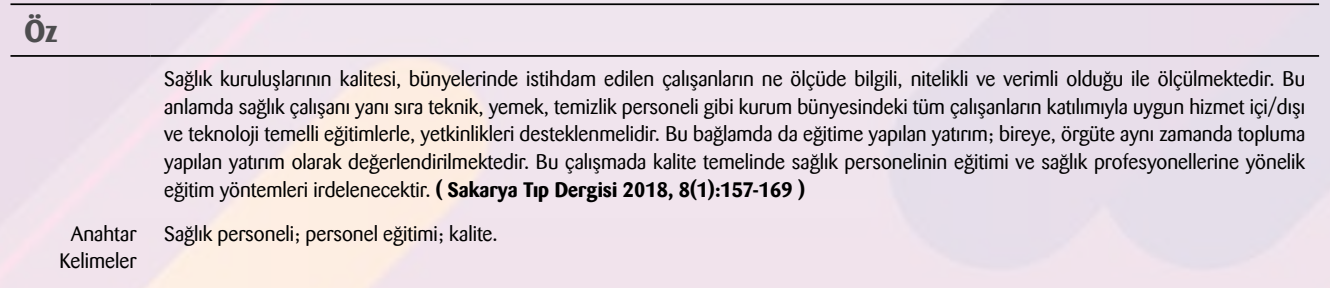

Abstract

The quality of the health institutions is measured by the degree of knowledge, qualified and efficiency of the health workers employed in the organizations. Therefore, the competence of employees with appropriate in-service training, non-service training, and technology-based trainings should be supported with the participation of all employees within the institution, such as technical, food, cleaning personnel as well as health workers. In this context, the investment made in the training is evaluated as investment in the individual, organization and society. In this study, based on quality, training methods of health personnel and education for health professionals will be examined. ( Sakarya Med J, 2018, 8(1):157-169 ).

Key Words Health personnel; staff training; quality 
Sakarya Tıp Dergisi 2018;8(1):157-169

\section{Giriş}

Günümüzün küresel rekabet ortamında kalite düzeylerini ve standartlarını geliştirmek özel ve kamu kuruşlarının öncelikli hedeflerini oluşturmaktadır ${ }^{1}$. Sağlık hizmetlerinin amacı, toplumun gereksinim duyduğu sağlık hizmetlerini, hastanın istediği zamanda, minimum maliyetle ve istenilen kalitede sunmaktır². Yaygınlaşan iyi bakım talepleri, artan maliyetler, hasta şikâyetleri, sağık hizmeti veren kurumları değer bazlı sağlık hizmetlerine ve kaliteye yöneltmektedir.

\section{Kalitenin Tanımı}

Kalite kavramı geçmişten günümüze kadar değişik alanlarda birçok düşünür ve uzman tarafından farkı şekillerde tanımlanmışıı ${ }^{3}$ Juran kaliteyi "kullanıma uygunluk”, Taguchi "ürünün müşterilerin eline geçtiği andan itibaren vermiş olduğu zararın minumum seviyede olması", Crosby "gereksinimlere uygunluk" ${ }^{4}$ Feigenbaum ise "müşterilerin belirli koşulları için en iyisi" şeklinde tanımlamaktadırlar ${ }^{5}$. Kalite kavramı; "ürün ve hizmette hata ve yanlışların olmaması", "mal veya hizmette mükemmeliyet derecesi” olarak ta tanımlanmaktadır ${ }^{6}$. Tanımların bu kadar çeşitli olmasının nedeni kalitenin çok boyutlu bir kavram olmasından kaynaklanmaktadır

Sağlık hizmetlerinde de benzer şekilde birçok kalite tanımı bulunmaktadır. Sağlık kuruluşlarında hizmet kalitesi, genel olarak "sağlık hizmetleri sisteminin çeşitli öğelerinin, standartlara uygunluğu ya da mükemmellik derecesi” olarak tanımlanır². ABD Tıp Enstitüsü (Institute of Medicine) ise aynı kavramı "bireylere ve topluma sunulan sağlık hizmetlerinin, arzulanan sağlık sonuçlarına ulaşma olasılığını artırma ve şimdiki profesyonel bilgiyle tutarlı olma derecesi” olarak tanımlamaktadır8. Donabedian yüksek kalitedeki bir sağlık hizmetini "hizmet sürecinin bütün aşamalarındaki beklenen kazançlar ve kayıplar dengesi hesaba katılıktan sonra, hastanın iyilik halini en üst düzeye çıkaran hizmet" olarak betimlemektedir ${ }^{5}$. Kaliteli ürün veya hizmet; beklentileri karşılamak ve aynı zamanda bu beklentileri aşmaktır. Beklentiler ise değişebilir ve bu nedenle de kalite sürekli geliştirilmelidir ${ }^{9}$.

ABD Tıp Enstitüsü tarafından 2001'de yayınlanan raporda (Crossing the Quality Chasm: A New Health System for the 21st Century) sağlık bakım sisteminde kalitenin boyutları olarak kabul edilen ve iyileştirilmesi gereken; güvenlik, etkililik, hasta merkezlilik, zamanında, verimlilik ve adalet olmak üzere altı boyutu açıklanmıştı ${ }^{10}$. Aynı şekilde kaliteyi tanımlamaya yardım edecek bu boyutların yanı sıra; kabul edilebilirlik, erişilebilirlik, hakkaniyet ve uygunluk boyutlarından da bahsedilmektedir ${ }^{11}$. Kalite konusunda herkes tarafından kabul edilmiş ilkelere rastlamak zordur. Deming'den bu yana kadar gelen süreçte kalite çalışmaları ile yeni kavramlar ve kriterler anılmakta; özel ve kamu sektöründe ayrı ayrı ilkeler öncelik kazanmaktadır ${ }^{12}$.

\section{Sağlık Hizmetlerinde Kalitenin ilkeleri}

Kalite yönetimi temel ilkeleri içinde; hasta odaklılık, liderlik, çalışan katılımı, süreç yaklaşımı, iyileştirme, kanıta dayalı karar verme, ilişki yönetimi ve çalışan eğitimi yer almaktadır ${ }^{13}$. Bu kavramları kısaca açıklarsak:

Hasta /Birey Odaklılık: Kalite yönetiminin odak noktası, hasta beklentilerini karşılamak ve bu beklentileri aşmaktır. Sağlık kurumları da dâhil tüm organizasyonlar, ilgili tarafların güvenini kazandığında sürekli başarıyı yakalayabilirler. Sağlık hizmetlerinde müşteri olarak değerlendirilebilecek hastalarla olan her etkileşim, daha fazla değer yaratmak için bir firsat niteliğindedir. Hastaların mevcut ve gelecekteki ihtiyaçlarını anlamak, organizasyonun başarısının devamlı olmasına katkıda 
bulunur ${ }^{14}$. Bu da sağlık personellerinin hem bireysel hem de mesleki yeterlilik olarak tatmin edilmesiyle gerçekleşebilir.

Liderlik: Her kademedeki liderler, çalışanların ve kuruluşun kalite hedeflerine ulaşmasında amaç ve yön birliği kurarak uygun koşullar yaratmaktadır. Liderler, bir organizasyonun amaçlarını gerçekleştirmek için stratejileri, politikaları, süreçleri ve kaynakları organize eder ${ }^{14}$. Deming'e (1994) göre aynı zamanda işletmenin sürekli gelişmesi için üst yönetim, sistemde değişiklikler yaparak çalışanların iş güvencelerini sağlamalı ve kurumsal bir vizyon belirlemelidir ${ }^{13}$. Ayıca uzun, orta ve kısa vadeli planların yapılması ve bunların kurumsal amaçlarla uyumlandırılmasındaki temel rolü üst yönetim üstlenmelidir. Bunun içinde de bu pozisyonunda bulunanların konuya ilişkin eğitimi önemlidir $^{15}$. Sorumluluğu altında bulunan bireyleri yönlendirmek, motive etmek için güçlü bir iletişim yeteneğine ve kurumsal alt yapıya ihtiyaç duyulur. Bu anlamda da liderlerin motivasyon faktörleri, iletişim teknikleri ve yetkinliklerine dair yeterli bilgi ve beceriye sahip olması, belirlenen hedeflere ulaşmada ve planların gerçekleştirilmesinde payı büyüktür.

Çalışanların Katılımı: Organizasyonun her düzeyinde yetkin, değer yaratma ve bu değeri sunma kapasitesine sahip, sorumlulukları konusunda yetkilendirilmiş çalışanlara ihtiyaç duyar 14 . Kurumların gösterdikleri faaliyetlerin hemen her aşamasında ortaya çıkabilecek sorunların, farklı bakış açılarına sahip kişiler tarafından ele alınması, sorunun en uygun çözümle giderilmesini sağlamaktadır. Bu yüzden kalite yönetim felsefesinin vazgeçilmez unsurlarından biri de bu fırsatı sunan planlı takım çalışmalarıdır ${ }^{12}$. Başarıı bir hizmet üretimi için üst yönetiminden başlayarak tüm çalışanların düşünme ve uygulama aşamalarına bir takım halinde katılımının sağlanması önemlidir ${ }^{15}$.

Süreç Yaklaşımı: Deming'in yönetim metotlarının altında yatan kalite yönetiminin teorik olarak açıklamaya çalışan Anderson ve Rungtusanatham (1994)'e göre bu yaklaşım sonuçlardan ziyade sürecin veya eylem araçlarının yönetimini vurgulayan metodolojik ve davranışsal uygulamalar seti olarak ifade edilmektedir. Buna; süreçlerin yönetimi, önleyici tedbirlere yönlendirme, kitle muayenesinin azaltılması, tasarım kalitesi, istatistiksel süreç kontrolü, varyasyon anlayışı, motivasyonun anlaşılması, toplam maliyet muhasebesi, istikrarlı bir istihdam sağlanması; sayısal kotaların, amaçlara göre yönetimin ve liyakate göre ödül sistemlerinin ortadan kaldırılması örnek verilebilir ${ }^{16}$.

Illişki Yönetimi: Bir kuruluşun en iyi performansını sergilemesi; işbirliği yaptığı kuruluşlarla karşılıklı güven sağlamasına, bilgi birikiminin aktarılmasına ve bütünleşmeye dayalı, karşılıklı fayda sağlayan ilişkiler kurmasına bağlıdır7. Sağlık kurumları açısından bakıldığında ise ilaç şirketleri, sigorta kurumları, medikal cihaz satıcılar gibi tedarikçilerle sağlanan ilişkilerin yönetimi kalitenin sürdürülmesi açısından önemlidir.

Kanita Dayalı Karar Verme: Karar verme her zaman bir miktar belirsizlik içermektedir. Genellikle bu süreç çeşitli türde girdi kaynağı, öznelliğin yanında kişisel yorumları da içerir. İstenilen sonuçları üretmek için kararlar, veri ve informasyonun değerlendirilmesi ve analizine dayanır. Kanıtlar ve veri analizi, daha objektif, aynı zamanda güvenli kararlar alınmasına öncülük eder ${ }^{14}$.

Sürekli İyileştirme: Sürekli iyileştirme, kuruluşun, süreçleri, ürünleri ve hizmetleri için aşamalı ve yenilikçi iyileştirmeler yapma eğilimidir ${ }^{16}$. Ölçemediğinizi geliştiremez ve iyileştiremezsiniz9. Dolayısıyla sağlık hizmetlerinde kalitenin sağlanmasında ve sürdürülmesinde sürekli ölçüm ve değer-
Sakarya Tip Dergis

2018;8(1):157-169

ALTINDiş ve Ark.

Kalite Bağlaminda

Sağlik Personeli Eğitimi 
Sakarya Tıp Dergisi 2018;8(1):157-169 lendirmeler yapılmalıdır ${ }^{18}$. Ölçüm ve değerlendirmelerin iyi olması için de istatistiksel yöntemlere ihtiyaç duyulmaktadır ${ }^{19}$. Sürekli iyileştirmede, mevcudun daha da iyileştirilebileceği varsayımıyla hareket edilir. Ancak bu iyileştirmede insan kaynaklarını yani her çalışanı iyileştirme faaliyetlerinin bir parçası haline getirmek temel zorunluluktur. Ayrıca mevcudu geliştirmek ve sorunları çözmek üzere problem çözme tekniklerinin yaygın bir şekilde kullanımı önemlidir. Dolayısı ile çalışanların problem çözme becerilerini geliştiren, yaratıclıklarını ve bireysel yeteneklerini ortaya çıkarmaya yarayan eğitimler planlanmalıdır ${ }^{20}$.

\section{Kalite Bağlamında Çalışan Eğitimi}

Çalışan Eğitimi: Çalışanların şimdi ve gelecekte ortaya çıkabilecek gereksinimlerini karşılamak, bilgi ve becerilerini ilerletmek, tutum ve davranışlarını istenen şekilde değiştirmeye yönelik faaliyetler bütünüdür ${ }^{21}$. Bu konuda Deming başarılı bir eğitim programının; sürekli değişim ve gelişim sürecindeki önemini vurgulayarak çalışanlarda örgütsel bağllığın artması, doğru davranış kalıplarının yerleşmesi, artan iş birliği, mesleki gelişim gibi konularda da faydalı olacağından bahsetmişti ${ }^{13}$. Ayrıca eğitim; en tepedeki yöneticiden başlayarak tüm çalışanları kapsayacak şekilde verilmelidir ${ }^{15}$. Alanlarına ilişkin eğitimler ile sağık çalışanları, değişim ve yenilikleri takip edebilecek, en iyi uygulamaları transfer edecek, gerekli yetenek ve becerilerle donanmış olarak verdikleri hizmetin kalitesini de artıracak yada mevcut kalitelerini sürdürebileceklerdir. Ĕgitim aracilığı ile artmış yetkinlikler, hatasız, etkili ve verimli sağlık hizmeti sunma yönünde sağlık çalışanlarına destekleyecektir.

Ayrıca eğitim programları içinde kalite konusunda bilgilendirme, takım çalışması becerisi kazandırma, süreç yönetimi, kalite ölçüm yöntemleri, istatistiki yöntemler ve hasta bilinci oluşturma gibi bazı eğitim programları da yer alır. Elde edilen sonuçlarına göre verilen eğitimler şu şekilde sınıflandırılabilir ${ }^{15}$ :

Iş bilgisi ve beceri kazandırmaya yönelik eğitimler: Sağlık hizmetlerinde yeni yöntemler ve cihazları kullanabilme becerisi kazanmaya ilişkin eğitimler yanı sıra temel kalite teknikleri, iletişim teknikleri, süreç kontrol teknikleri, problem çözme ve istatistiksel yöntemlere ilişkin eğitimler

Davranış değişikliğini sağlamaya yönelik eğitimler: El hijyeni sağlama, hata raporlama sistemlerini kullanma eğitimleri, liderlik, zaman yönetimi ve kendi kendini yönetme eğitimleri vs

Tutum değişikliğini destekleyici eğitimler: Hasta memnuniyetini sağlamaya yönelik anlayışı kazanma, takım çalışması, katılımcı yönetim, süreç yönetimi, değişim yönetimi ve yöntemlerine vs uyum sağlamaya ilişkin eğitimler.

Programların ilk evrelerinde tutum değişikliğine ilişkin eğitimler ön planda iken sonraki aşamalarda bilgi ve beceri kazandıııı eğitimlere odaklanılmaktadır ${ }^{15}$.

\section{Eğitim yöntemleri}

Eğitim yöntemleri; iş başında, iş dışında ve teknoloji temelli eğitim yöntemleri şeklindedir ${ }^{22}$. Ayrıca yeni nesil sağılk hizmetlerinde eğitimler; tıbbi simülasyon, simüle edilmiş/ standardize hasta eğitimlerinin yanı sıra bilgisayar odaklı, ekran temelli, sanal gerçeklik(virtual reality), artırılmış gerçeklik (augmented reality) $)^{23,24}$ ve karma ya da hibrit gerçeklik (mixed reality), eğitimlerini de kapsamaktadir. 


\section{iş̧ Başında Eğitim:}

iş başında eğitim yöntemleriyle eğitim alan çalışan, organizasyon içerisinde işinden ayrılmadan, işini yaparken eğitim almaktadır. Bu eğitim yönteminin eğitim süresi boyunca işlerin aksamaması, çalışanların öğrendiklerini uygulamalı bir şekilde yaparak işe/ortama uyum sağlaması ve daha az maliyetli olması gibi üstünlüklere sahiptir ${ }^{25,26}$. Genellikle birinci derece amir veya nadir olarak da uzman öğreticiler tarafından eğitim verilmektedir ${ }^{26}$. Başıı̆ı iş başı eğitim yöntemleri ise şunlardır ${ }^{22}$ :

- $\quad$ Öz yönelimli öğrenim

- Çıraklık

- Yönetici gözleminde eğitim

- Staj yoluyla eğitim

- Oryantasyon (işe alışıırma) eğitimi

- Formen aracılığı ile eğitim

- iş rotasyonu

Öz yönelimli öğrenim: Öğrenme aşamasının başından itibaren öğrenen kişinin kendi hedeflerini belirlemesi, çalışma stratejisi oluşturması ve sonuçlarını değerlendirmesini içermektedir ${ }^{27}$. Sağı̆ık hizmetlerinde laboratuvar teknisyeninin bakteri kültür ayrışıırmasında tek koloni düşürme tekniğini, ilgili uzmanından öğrenmek istemesi, öğrenme sonrasında yetkinliğini de sonuçların başarısı ile görebilmesi, bireyin kendisini geliştirmesi istemine bir örnek olabilir.

Çıraklık: Herhangi bir meslek grubunda gerekli olan bilgi, beceri ve iş alışkanlıklarını, çalışma süresince geliştiren çıraklar, mesleki eğitim programları ile yaş ve eğitim seviyelerine göre çıraklık eğitimi alabilmektedirler ${ }^{28}$. Hastanelerde sağlık hizmetlerinde kuruma ve işe yeni başlayan bireylere hastane oryantasyon eğitimi sonrasında hemen görev verilmez. Konunun uzmanı/kıdemlisi ya da sorumlusu yanında bir süre gözlemci olarak bulunması istenir. Sonrasında yine uzmanın gözetiminde işi kendisinin yapması sağlanır. Bu şekildeki uygulamalar sağlık hizmetlerinde çıraklık eğitimine örnek olabilir. Örneğin ortopedi uzmanlığı eğitimi süresince ilk kırık tespitinden komplike vakalara müdahale yetkinliği kazanana kadar geçen süreç bu eğitim modeline örnektir. Benzer şekilde radyolojide film okuma ve yorumlamalarda kıdemliden öğrenilecek teknik bilgilerle elde edilen beceri yine bu grup öğrenmeye örnektir.

Yönetici gözleminde eğitim: Gözetimci nezaretinde eğitim olarak da bilinen uygulaması kolay, maliyeti düşük, eski eğitim yöntemlerinden biridir. Bu eğitimde işe yeni başlayan ya da iş değişikliği gerçekleştirmiş bir çalışanın; işle ilgili bilgi beceri ve tecrübe sahibi başka bir çalışanın yanında eğitime tabi tutulmasıdır. Ancak eğitimi verecek olan çalışanın iş ile ilgili bilgi beceri ve tecrübelerini aktarma konusunda yaşayacağı herhangi bir sorun bu eğitim yönteminin sakıncaları arasında gösterilmektedir ${ }^{25}$. Uzmanlık eğitimine başlamış yeni mezun bir doktorun uzmanlık eğitimi boyunca elde edeceği tüm beceriler bu eğitim modeliyle gerçekleşir. Diş hekimlerinin lisans eğitimlerinde ilk önce laboratuvar ve simülasyon alanlarında yeterince beceri kazandıktan sonra kliniklerde hasta üzerinde yapılan uygulamalar yönetici gözetimindeki eğitime örnektir.

Staj yoluyla eğitim: Iş̧ gören adaylara iş hakkında sahip oldukları teorik bilgiyi pratiğe dökmek adına belirli bir süre zarfında, iş ile ilgili çalışma koşullarını tanıma, işi öğrenerek sorumluluk kazanma ve iş yeteneklerini geliştirme gibi konularda kazanım sağlayan bir eğitim yöntemidir. Ayrıca yönetici adaylarının yetiştirilmesinde; liderlik, planlama, koordine etme, kontrol, stratejik düşünerek karar verme gibi yeteneklerinin geliştirilmesinde bu eğitim yönteminden faydalanılmaktadır29. Sağık
Sakarya Tip Dergisi

2018;8(1):157-169

AltiNDiş ve Ark.

Kalite Baglamnnda
Sağilk Personeli Egitum 
Sakarya Tıp Dergisi

2018;8(1):157-169

ALIINDis ve Ark:

Kalite Bağlamind

Sağllk Personeli Éğtimi

hizmetlerinde potansiyel çalışanlar, lise, ön lisans ve lisans eğitimi dönemlerinde belirli süre bir bu eğitimi almaktadır. Hatta bu eğitim, zorunlu eğitim kapsamındadır. Tüm sağlık birim ve bölümleri, staj yoluyla ilgili alanlarına yönelik süreçleri tanıma, ekip üyelerine entegre olma ve gerektiğinde uygulama yapma imkanı kazanırlar.

Oryantasyon (işe alıştırma) eğitimi: Organizasyonlarda işe yeni başlayan ya da kurum içi bölüm değiştiren çalışanlara işe başlamadan önce veya ilk günlerde uygulanan, süresi işin niteliklerine göre değişiklik gösteren, çalışanlara iş ile ilgili temel bilgi ve beceri kazandırarak işletmeye olan uyumunu kolaylaştırmayı amaçlayan eğitim yöntemidir ${ }^{25,29}$. Ayrıca çalışan oryantasyonu, hasta bakım hizmetlerini iyi bir şekilde sağlamak için hastane personelinin; gereken uygun niteliklere, sürekli eğitim ve öğretim olanaklarına sahip olması ve içinde bulunduğu olumlu koşullar neticesinde çalışmasından memnun olma derecesidir5. Bu yöntem, sağlık personelinin korku ve herhangi bir belirsizlik durumu içerisinde olmadan yetki, görev ve sorumluluklarını nasıl yerine getirebileceğini öğrenmesini sağladığı için önemlidir ${ }^{30}$. Bir sağlık örgütünde kurum içi ya da kurumlar arası yer değiştirmelerde birime yeni başlayan bireye, işleyiş, süreçler, yapılması ve dikkat edilmesi gereken hususlar, ast-üst ilişkileri, yazışma teknikleri, ekip üyeleri ile tanışma ve entegre olma gibi alanlarda işe alışırma eğitimi verilir. Örneğin yeni başlayan bir doktor ya da hemşire, laboratuvarlar, kan bankası, eczane hizmetleri, döner sermaye hizmetleri, idari işleyişle alakalı tüm konular, hasta ve çalışan güvenliği konuları, kullanılan formlar ve dijital kayıtlar, yatış ve taburculuk hizmetleri gibi birçok konuda oryantasyon eğitimi alır.

Formen aracılığı ile eğitim: Kılavuz aracilığılla eğitim olarak da adlandıılan bu yöntemde çalışanlar arasından seçilen kişiler teknik ve pedagojik bilgilerle donatılarak verilecek eğitiminde görevlendirilmektedir. Bu yöntemde formenler; iş ile ilgili genellikle yapılan hataları, nedenlerini, çözüm yollarını veya kullanılan araçların daha ekonomik daha kolay kullanılması ile ilgili pratik bilgileri iş başında anlatarak çalışanlara yol göstermektedir ${ }^{25}$. Kan transfüzyonu reaksiyonlarını azaltmak için klinik sorumlusu süpervisior hemşirelerin kendi eğitimleri sonrasında o klinikte çalışan diğer hemşire arkadaşlarını da deneyim ve bilgi birikimi ile eğitmeleri, çalışmalarını kontrol etme ve uygulama süreçlerini takip ederek değerlendirmeleri bu eğitime örnek verilebilir.

İş rotasyonu: Çalışanlara organizasyon içerisinde çeşitli bölümlerde belirlenen zamanda bir plana uygun olarak eğitim vermeyi içeren; farklı işlerde çalışıııııma sayesinde deneyim ve beceri kazanımını sağlayan eğitim yöntemidir. Bu sayede sürekli aynı işi yapmaktan dolayı tatminsizlik yaşayan çalışanlar, iş yaşamlarının birkaç gününü, haftasını veya yılını, organizasyonun farklı bölümlerinde çalışarak geçirmekte ve böylece iş zenginleştirme sağlanarak çalışan memnuniyeti artmaktadır. Aynı zamanda bu yöntem üst ve orta kademe yöneticiler için ileride gerçekleşebilecek önemli atamalarda organizasyondaki çeşitli bölümlerin tanınmasında ve teknik becerilerin arttırılmasında kullanılmaktadır ${ }^{29}$. Sağlık hizmetlerinde ise tıbbi personel, aynı departmanın farklı birimlerinde görevlendirilir. Örneğin mikrobiyoloji uzmanlık eğitiminde genel olarak mikrobiyoloji alanındaki ilgili bilgilerini öğrenmek ya da güncellemek için alt disiplin laboratuvarlarına (ELiSA laboratuvarı, parazit laboratuvarı, bakteriyoloji laboratuvarı vb.) iş rotasyonu uygulanır. işs rotasyonu, tecrübe ve uygulama becerilerini geliştirerek çalışma ruhunu teşvik eden, çalışma alanlarının genişlemesine yardımcı olan eğitim yöntemidir. İş rotasyonunun sıklı̆ı, çalışanların geçmiş deneyimleri, öğrenme 
durumu ve mesleğe olan alışkanlık düzeyi gibi bazı faktörler dikkate alınarak oluşturulmalıdır ${ }^{31}$.

\section{İş Dışında Eğitim:}

Kurum dışında düzenlenen bu eğitim programında çalışanlar günlük iş hayatlarının etkisinden ayrılarak nesnel düşünme, tartışma ve genel ilkeler üzerine kurum içinde verilen eğitime oranla daha fazla odaklanmaktadır ${ }^{32}$. İş dışı eğitimler alanında hizmet veren, belirli konularda uzmanlaşmış eğitim ve danışmanlık şirketleri bulunmaktadır ${ }^{25}$. İş dışındaki eğitim yöntemleri aşağıdaki gibi sıralanabilir ${ }^{22,33}$ :

- Konferans, Seminerler ve Kongre

- Simülasyonlar

- Duyarlılık eğitimi

- Vak’a çalışması (örnek olay) yöntemi

- Işletme oyunları

- Rol oynama

- Davranış modelleme

- Grup kurma metotları

- Standart hasta yöntemi

Konferans, Seminer ve Kongre: Konferans bir tezi, görüşü veya bir konuyu açıklamak için verilen, bilgi aktarma yoluyla gerçekleşen bir hitap türüdür. Seminer ve konferansların; belirli bir konuda bilgi vermek amacıyla düzenlenmesi gibi sayılabilecek birçok ortak yönleri vardır. Bunun yanı sıra seminerler birkaç oturum şeklinde gerçekleşip daha uzun sürmesi ve akademik olarak daha yaygın olması açısından konferanstan ayrılmaktadı ${ }^{25}$. Kongre ise, geniş katılımlı, bir konu ya da alanın farklı oturumlarla enine boyuna tartışıldığı eğitim platformlarıdır. Son yıllarda sağlık alanında her sağık profesyonelini ilgilendiren farklı alt başlıklarda çok sayıda kongre, seminer ve konferans düzenlenmektedir. Bu uygulamalar bir eğitim biçimi olarak son yıllarda yaygın şekilde kullanılmaktadır. Hatta Sağlık Bakanlığı, kendi personeli yanı sıra diğer sağlık kuruluşlarında çalışan bireylere yönelik gerek eğitimlerini desteklemek, gerekse de konuya ilişkin farkındalık yaratmak ve davranış değişikliğine dönüştürmek üzere kongreler düzenlemektedir.

Simülasyonlar: Eğitilenlere iş yaşamlarında verdikleri kararların ne gibi sonuçlar doğuracağını göstererek gerçek yaşamda bulunan bir durumu temsil eden eğitim yöntemidir. Yönetim, kişiler arası beceriler, üretim ve işletme becerilerinin öğretilmesinde kullanılan yöntemde, eğitim gören bireylerin vermiş oldukları kararların sonuçlarını yapay ve risksiz ortamlarda görmelerine olanak tanır34. Sağlık bakım hizmetlerinde kullanılan simülasyon ise klinik karar vermeyi, düşünmeyi ve klinik çevrenin gerçekliğine benzer olma gibi eylemlerini içeren işlemleri canlandırmayı hedeflemektedir. Sağlık eğitiminde kullanılan simülasyonların gelişen teknoloji ile geniş eğitim materyali olarak sunduğu basitten karmaşığa doğru çeşitlenen şekilleri bulunmaktadır ${ }^{35}$. Tıp, eczacılık veteriner hekimlik, diş hekimliği gibi birçok sağık disiplininde simülasyonların lisans, önlisans ve mezuniyet sonrası eğitimlerde kullanıldığı görülmektedir. Bu eğitimlerle, hastaya zarar vermeksizin, gerçeğe en yakın, birebir benzer uygulama alanı ve ortamı oluşturularak mesleki beceri kazanılması söz konusu olabilmektedir. Bu konuda ABD Florida'da sadece simülasyonla eğitimin gerçekleşmesi için özel merkezler kurulmuştur. Bu merkezlerde simüle edilmiş hasta müdahale odası, hasta muayene ve acil durum oda modelleri oluşturulmuştur. Bu odalar, hastane yatak veya sedyeleri, monitörleri, defibratörler, tansiyon manşonları, simüle oksijen maskeleri ve acil durumlar da dahil olmak üzere
Sakarya Tip Dergisi

2018;8(1):157-169

Altindis ve Ark.

Kalite Baglamnda
Sag̈lik Personeli Eggtim 
Sakarya Tıp Dergisi

2018;8(1):157-169

ALTINDiş ve Ark Kalite Bağlaminda Sağllk Personeli Ĕgitim

tıbbi ve hemşirelik müdahalelerine cevap vermek için gerekli tüm teçhizat ve malzemelerle tam donanımlıdır. Bu merkezlerde, yüksek kaliteli wireless, tam gövde erkek ve kadın mankenler kullanilır. Yüksek gerçekli hasta simülatörler ( high fidelity patient simulator), alınan tüm aksiyonları ve hastalara verilen tüm farmakolojik ajanları izler. Yanlış ilaç veya dozajlar uygulanırsa, yüksek kalitede ve doğala en yakın şekilde yani canlı bir hastanın reaksiyonuna benzer şekilde mankenler tepki verir. Florida Atlantik Üniversitesi Simülasyon Merkezi (FAUSC) tıp öğrencileri, uzmanlık eğitimi alanlar, hemşireler, acil tıp teknisyenleri, evde bakım hizmeti verenler gibi birçok sağlık profesyoneli ve adayını, kendi alanlarında eğitmek için geliştirilmiş simülasyon, eğitici teknolojilerini kullanmakta ve bunları eğitim müfredatlarına entegre etmektedir. Böylece bireylerin ileri teknolojiye aşina olmaları, klinik becerileri ve eleştirel düşünmelerini geliştirmeleri, uygulama konusunda özgüvenli olmaları, çalışma ortamında paniğe kapılmamaları gibi faydalar sağlamaktadır ${ }^{36}$.

Duyarlılık Eğitimi: Bu eğitim yöntemi literatürde T-Grup, beşeri ilişkiler eğitimi ve laboratuvar eğitimi olarak adlandırılmakla beraber genellikle üst düzey yöneticilerin eğitiminde kullanılmaktadır 26 . Kişileri mesleki ve teknik yönden eğiterek, organizasyon içerisinde kişilerin diğer personellerle verimli çalışmasını aynı zamanda işbirliği yapabilme yeteneğinin etkin bir şekilde gelişmesini amaçlamaktadır ${ }^{37}$. Ayrıca De Vinci (2010) sağlık çalışanlarının duyarlılık eğitimini incelediği çalışmasında alıntı yaptığı Kjeldmand ve arkadaşlarının (2004) duyarılık eğitimi alan hekimlerin hastalarıyla daha iyi ilişkiler geliştirdiğini ve çalışmalarından daha memnun olduklarını saptamıştır. Bu çalışma sağlık çalışanlarında duyarlılık eğitimlerinin işlerine pozitif yansımalarının olabileceğini belirtirken Paez ve arkadaşları (2007), Alpers and Zoucha'nın yapmış oldukları çalışmada duyarlılık eğitiminin duyarlılık becerilerindeki davranış değişikliklerini veya yeterlilikleri garanti etmediğini bildirmektedir ${ }^{38}$.

Vak'a çalışması (örnek olay) yöntemi: Yöntemde eğitim verilen gruba hayali ya da gerçek bir olay verilerek eğitim yapılmaktadır. Bu olayın grup içinde ayrıntılarılla incelenip yorumlanmasını sağlamak; bireylerin bilinçli düşünmeye, çözüm yolları bulmaya ve etkili karar almaya yönlendirmek yöntemin temel amacı olarak gösterilmektedir ${ }^{39}$. Özellikle sağlık bakım hizmetlerinde sıkça karşılaşılan etik sorunların değerlendirilmesi için vaka analiz yönteminin kullanılması önerilmektedir ${ }^{40}$. Bu eğitim modeline örnek olarak tıp fakültelerinde ülkemizde 2000'li yıllardan beri kullanılmakta olan probleme dayalı öğretim (PDÖ) biçimi verilebilir. Bir eğitici başkanlığında oluşturulan klinik vaka senaryosunun öğreniciler ya da eğitilenler ile adım adım çözümlenmesi (tanı ve tedavisi) yöntemidir ${ }^{41}$. PDÖ'de yazılı senaryolar, anekdotlar, resimler, drama gibi yöntemler yanı sıra video, teyp gibi araçlar kullanılır ${ }^{42,43}$. Örnek bir vaka senaryosu hazırlanır. Bu senaryo üzerinden beyin fırtınası yapılarak olası hastalık semptomları, hastalık prognozu, tanı tedavi süreçleri, komplikasyonları düşünülür ve bulunur. Böylece sahip oldukları bilgiyi kullanma, bilgilerin analizini ve sentezini yapma, değerlendirme becerisi kazanma gibi kazanımlar sağlanır. Bu yöntemle öğrencilerin problem çözme yeteneklerinin artııııması ve gerçek yaşam/klinik problemler kapsamında temel tıp bilgilerinin edindirilmesi amaçlanmaktadır. Bu yöntemle tıp öğrencisinin önceki bilgilerine ilave olarak küçük bir grup ve senaryo ile etkileşimi sağlanarak kendine özgü yeni bilgilerini oluşturması hedeflenir. Profesyonel meslek yaşamında karşılaşma ve kullanma potansiyeli olan klinik vakalar ile öğrenim yapılmaktadır ${ }^{41}$. Aynı zamanda orta kademe yöneticilerin geliştirilmesinde de kullanılan bu yöntemde verilen olay, eğitim gören kişiler arasında tartışılarak kararı etkileyen etkenler incelenir ve çözüm yolları üretilir. Yapılan karşılıklı fikir alışverişinden sonra en iyi çözümü seçip uygulamaları istenir. Buradaki amaç yöneticileri iş yaşamlarında karşlaşabilecekleri olası sorunlara hazırlamaktı ${ }^{44}$. 
Standart hasta yöntemi: Standardize hasta, belli bir hastalığa ilişkin doğru öykü ve muayene bulguları tablosu çizebilerek dikkatle eğitilmiş normal bir kişi ya da kendi hastalıklarını standart ve değişmeyecek şekilde anlatacak şekilde eğitilmiş gerçek hastaları içeriir ${ }^{33}$. Bu yöntemde öğrenim hedeflerine göre hasta ve ortamın özellikleri belirlenir ve hasta rolü yapacak kişiye hastalığı ile ilgili klinik bilgileri, semptomları hakkında bilgilendirme yapıldıktan sonra oluşturulan bir senaryo ile standart tipte bir hasta yetiştirilir. Daha sonra öğrenciler bu yetiştirilen standart hastalarla görüşme yapar ve bu görüşmeler kamera ile kaydedilir. Görüşme sonunda standart hastalar, hekim adaylarının davranışları, sorması gereken soruları, yapması gerekenleri yapıp yapmadığı ile ilgili geribildirim verir. Standart hasta yöntemi, öğrenicinin kayıtlarının izlenmesiyle çözümlemelerin yapıldığı bir yöntemdir. Burada rol alan standart hastalar, gerçek hastaları simüle etmek için seçilmiş ve eğitilmiş gönüllü bireylerden ya da belirli fiziksel muayene bulguları olan gerçek hastalardan oluşur ${ }^{33,45}$. Bu yöntemde öğrenci, klinik beceri eğitim merkezlerinde farklı ortamlarda bulunan standart hastalarla görüştürülerek sanki gerçek hastayla görüşüyormuş gibi bilgi ve becerisini burada test etmiş olur. Daha sonra standart hasta ile eğitimlerde alınan kamera kayıtları öğrencilerin kendilerini değerlendirmesinde kullanılır. Böylece öğrenci kendi performansını değerlendirme imkanına sahip olur. Standart hasta tekniği, Amerika ve Avrupa'da eğitim veren çoğu tıp fakültesinde kullanılmaktadır. Ayrıca mezuniyet sonrasında bu teknikle sağık personelinin eğitimi sağlanmaktadır. Bu yöntem, bireylerin iletişim becerilerinin geliştirilmesi, kronik hastalık yönetimi, klinik beceri kazanımının kolaylaştııılması amacıyla kullanılmaktadır ${ }^{45}$.

Ayrıca gerek tıp gerekse hemşirelik öğrencilerinin/çalı̧anlarının bilgi ve beceri eğitimlerinin istenen zamanda, güvenli ve kontrollü bir ortam içinde tekrarlanabilir şekilde standart hasta uygulaması ile desteklenmesiyle kuramsal bilginin pratiğe dönüştürülmesi, etkili iletişim ve görüşme becerilerinin geliştirebilmesi, kritik düşünme ve problem çözme yeteneği edinilmesi, özgüven ve motivasyon düzeylerinin artırılmasına yardımcı olduğu belirtilmektedir46. Standardize hasta uygulamasının tıp eğitimi, araşııma ve sürekli tıp eğitiminde hasta ve hekimlerin gereksinimlerini belirlenmesinde de yararlanılabilir 4 .

Davranış modelleme: Fiili yöntemlerden farklı olarak beceri ve davranışları öğreten bir modeldir. Bu yöntem, eğitim gören bireylere davranışlaını tekrar edebilecekleri bir model ile temel davranışları uygulayabilme olanağı sağlamaktadır. Eğitilenlere kendi davranışlarıyla modellenen temel davranışın ne kadar uyum sağladığına bakılarak değerlendirme yapilır. Yapılacak olan eğitimde bir model tarafından gösterilen davranışları inceleyerek modelin pekiştirildiğini görmeyi vurgulayan Sosyal Öğrenme Teorisini benimseyen bir yöntemdir ${ }^{34}$. Sosyal Öğrenme Teorisi ise insanların bilgili ve güvenilir olarak gördükleri bireyleri dikkatli bir şekilde izleyerek öğrenimin gerçekleşmesi üzerinde durmaktadır ${ }^{34}$. Bu model, sağlık mesleği eğitimi alanında çevrimiçi etkileşimli incelemeler için çeşitli anlatımlar geliştirerek, eğitim alanların belirli karakter rolleri seçmelerine izin vererek veya bireysel olarak aldıkları kararların sonuçlarını görmelerini sağlayarak eylemlerinin sonuçlarını deneyimlemelerine izin verir ${ }^{48}$.

Grup kurma metotları: Eğitim gören bireylerin grup kimliği oluşturması, fikir ve yeteneklerini paylaşması, kişiler arasında gerçekleşen ilişkilerin dinamiklerini anlaması ile kendinin ve gruptaki çalışma arkadaşlarının güçlü ve zayıf yönlerini öğrenmesini içeren grup kurma, takımların kabiliyetlerini arttırarak verimli takım çalışması için oluşturulmuş bir yöntemdir. Ortak özellik olarak yeni bir takım kurmayı, takım performansını geliştirmeyi, farklı takımlar arasındaki etkileşimi sağlamayı amaçla-
Sakarya Tip Dergis

2018;8(1):157-169

AltiNDis ve Ark. Kalite Baglaminda 
Sakarya TIp Dergisi

2018;8(1):157-169

ALTINDiş ve Ark

Kalite Bağlaminda

Sağlkk Personeli Eğitim

yan; duygu, algı ve inançların inceleyerek tartısma yapmayı, öğrenilenlerin performansa aktarılması için planlar geliştiren birçok eğitim tekniği mevcuttur. Grup kurma metotları bu bağlamda macera öğrenimi, takım eğitimi, eylem öğrenimini kapsamaktadır ${ }^{34}$.

\section{Teknoloji Temelli Eğitim Yöntemleri:}

Kurumlardaki internet ve internet destekli bilgisayarlarla yapılan teknoloji temelli eğitim, son yıllarda kullanımı artan bir eğitim yöntemidir. Yapılacak yatırımın toplam maliyetinin ucuz olması, zaman ve mekân koşulunu ortadan kaldırması, değişimlerin takibini kolaylaştırması gibi avantajlarının yanında bu eğitimi alacak olan çalışanlardan eğitim altyapısı ve öz disiplin gibi nitelikler istemesi gibi bazı sakıncaları da bulunmaktadır. Bu eğitimler; bilgisayar temelli eğitim, multimedya eğitim, e-öğrenme, uzaktan eğitim, sanal gerçeklik ve artırılmış gerçeklik şeklinde değişik biçimlere sahiptir ${ }^{49,50}$.

Bilgisayar destekli eğitim; interaktif video, CD-ROM ve bilgisayar sürümlü diğer sistemleri içermektedir. Bu yöntem, uyarıcı rolde bulunan bilgisayarın, eğitilenlerin eğitim süresince verdiği cevapları analiz ederek geri bildirim sağladığı etkileşimli bir eğitim sistemidir ${ }^{34}$. Multimedya eğitim; işitsel ve görsel eğitim yöntemlerini bilgisayar destekli eğitim yöntemleri ile birleştirmektedir. Eğitim metodları içinde bilgisayar destekli öğrenme, CD-ROM, e- interaktif video, internet, sanal gerçeklik ve simülayonlar bulunur ${ }^{34}$. Uzaktan eğitim; coğrafi olarak dağınık bir şekilde farklı konumlarda birimleri bulunan kurumların çalışanlarına beceri ile uzmanlık eğitimi vermek, prosedür, politika ve yeni ürünler hakkında bilgi aktarmak için kullandığı eğitim yöntemidir ${ }^{34}$. E-öğrenme ise bilgi ve öğretimin paylaşılmasını ve anında güncellenmesini sağlayan elektronik ağlar içeren eğitimin internet ve web aracilığyla verilmesidir. Geleneksel eğitimin ötesine geçerek öğrenme çözümleri üzerinde duran yöntem; internet tabanlı eğitim, uzaktan öğrenme ve sanal sınıfları içerir ${ }^{34}$. Zaman ve mekân kavramlarına bağı kalınmadan mobil teknolojiler yardımıyla sunulan eğitim sürecine mobil öğrenme denir. Mobil öğrenme uygulamaları, cep telefonları ve avuç içi bilgisayarlarla yaygın olarak kullanılmaktadır ${ }^{51}$.

Kurumlarda uygulanan, daha fazla katılım ve sorumluluk alınmasını gerektiren kalite programları sayesinde tüm çalışanların eskisinden çok daha fazla ve farklı bilgi ve becerilerle donatılmış olması gerekmektedir. Kalite programları mesleki bilgi ve becerinin yanı sıra temel matematikten iletişim becerilerine, istatistik yöntemleri, olasılık hesaplama, analiz ve yorumlamaya kadar pek çok konuda bilgilendirilmiş insan gücünü talep etmektedir. Dolayısıyla eğitim bu ihtiyaçların karşılanabilmesi için tüm kalite programlarının ayrıımaz bir parçası konumundadır ${ }^{44}$.

\section{Sağlık Hizmetleri Kalitesinde Çalışanların Eğitimi ve Önemi}

Sağılık hizmetleri özellikle de hastane hizmetlerinin yapısı, içeriği, süreçleri ve sonuçları diğer hizmet sektörlerinden farklı olarak karmaşık bir özellik göstermektedir. Bunlara ilave olarak sağılık sisteminin insan sağı̆ğı ile olan doğrudan ilişkisi nedeniyle yapılacak herhangi bir hatanın insan hayatına mal olması da önemli bir etkendir. Sağlık personeli yanı sıra tıbbi araç ve gereçlerin yüksek maliyetli olması, artan sağlık hizmeti sunumu, gelişen teknolojinin takibinin zorunluluğu, maliyetleri artırmaktadır ${ }^{52}$. Özellikle yüksek hizmet kalitesinin beklendiği günümüz koşullarında önemli bir maliyet kalemini oluşturmasına rağmen sağlık hizmeti üreten kurumlarda önemli bir kaynak olan insan sermayesinin etkin ve verimli olması son derece önemlidir. Sağlık personeli özellikle kaliteli sağlık hizmeti üretiminin en temel aktörüdür ve bu aktörün bilgi ve becerisini içeren yetkinliklerinin 
düzeyi, kurum için çok değerlidir.

Günümüzde kuruluşlar tarafından eğitime yapılan yatııımların arış̧ı, insana verilen önemin yanı sıra bunun verimlilik üzerindeki etkisinin daha iyi anlaşıldığının da göstergesidir. Ayrıca sağık hizmetleri sunum yöntemleri ve kullanılan teknoloji hızla değişmektedir. Çalışanların bu değişimle baş edebilmesi için eğitim, temel rolü üstlenmektedir. Bu bağlamda da eğitime yapılan yatıım; bireye, örgüte aynı zamanda topluma yapılan yatıım olarak görülmektedir ${ }^{53}$.

Sağlık kuruluşlarının kalitesi, bünyelerinde istihdam edilen çalışanların ne ölçüde bilgili, nitelikli ve verimli olduğu ile ölçülmektedir. Sadece sağık çalışanı değil aynı zamanda yemek servisi, temizlik, teknik elemanlar gibi kurum bünyesindeki tüm personelin yetkinlikleri, kurumun üreteceği hizmetin kalitesinin belirleyicisidir ${ }^{54}$. Bu bağlamda sağlık hizmetlerinde kalite ve verimliliği arttırmaya yönelik çalışmalar yapılmasına rağmen yöneticilerin olumsuz tutumları, çalışanların işlerine olan isteksizliği ve temel mesleki eğitimdeki yetersizlikler gibi birçok neden, hataları ve sorunları arttırmaktadır. Bu nokta da yöneticilere ve çalışanlara önemli bir rol düşmektedir ${ }^{30}$.

Çalışanların tümünün katılımıyla sağlanacak hizmet içi eğitimleri, üretilen sağılı ve diğer hizmetlerin hatasız ve kusursuzluğu için ön koşuldur. Buradan yola çıkılarak sağlık kuruluşlarının bünyesinde bulanan tüm personelin eğitimine önem ve destek verilmesi gerektiği söylenebilir. Dolayısıyla bu eğitimlerinin düzenli şekilde planlanarak verilmesi ve belgelendirilmesi son derece önemlidir. Ayrıca kurum çalıştırdığı personelin 'nitelikli olma' sorumluluğunu almalı, personeli kurum iç olduğu kadar kurum dışı eğitimini desteklemeli ve bunun içinde uygun koşulları sağlamalıdır ${ }^{54}$.

\section{Sonuç}

Sonuç olarak kaliteli sağlık hizmeti için tüm çalışanlar, kalitenin önemli belirleyicileri konumundadır. Çalışan kaynaklı hataların minimalize edilmesi ve kusursuz sağık hizmeti üretmek için personel eğitimi gereklidir. İstenilen kalite düzeyini sağlamak üzere bu eğitimlerin periyodik olarak planlanarak uygulanması, bunların belgelendirilmesi ve tüm çalışanların bu eğitimlere katılımının sağlanması son derece önemlidir. Çünkü çalışanların kendilerine verilen görevleri eksiksiz yapmalarının yanı sıra zorunlu eğitim dönemlerinde edindikleri kazanımları, mesleki değişim ve gelişimlere uyum gösterecek şekilde revize etmesi için mesleki eğitimler gerekmektedir. Bu anlamda iş başında, iş dışında veya teknoloji temelli eğitim yöntemleri kullanılarak kurum bünyesindeki personelin sahip oldukları mesleki bilgi düzeyleri artıırlarak yeni tanı, tedavi yol ve yöntemlerine uyum sağlamalıdır. Ayrıca kurumda bulunan çalışanların sundukları hizmet sırasında, bireylerin bekledikleri kalite düzeylerinin de ötesine geçecek bir sağlık hizmeti sunmalarının, rekabet avantajı yaratmak için de gerekli olduğu düşünülmektedir.

\section{Çıkar çatışması:}

Yazar çıkar çatışması beyan etmemiştir.
Sakarya Tip Dergisi 2018;8(1):157-169

ALtindiş ve Ark. Kalite Bağlaminda Sağılk Personeli Eğtimi 
1. Özdemir MS. Öğretim Süreçlerinde Toplam Kalite Illkelerinin Uygulanmasının Öğrencilerin Tutumlarına Ve Başarılarına Etkisi. Kastamonu Eğitim Dergisi 2007;15(2):521-536.

2. Zerenler M ve Öğüt A. Sağlık Sektöründe Algılanan Hizmet Kalitesi ve Hastane Tercih Nedenleri Araştırması: Konya Örneği. Selçuk Ünversitesi Sosyal Bilimler Enstitüsü Dergisi 2007;18:501-519. doi:10.1017/ CBO9781107415324.004

Sakarya Tıp Dergisi 2018;8(1):157-169

3. Özgen H. Sağlık Bakım Hizmetlerinde Kalite Nedir Hasta Tatmini Boyutuyla Ilgili Bir Değerlendirme. Toplum ve Hekim Dergisi 2007;10(6970):47-53.

4. Sevimler S. Toplam Kalite Yönetimi Unsurları ve Unsurlarından Biri Olan Eğitim Ile İşletme Performansı Arasındaki ilişki. Dumlupınar Üniversitesi, Kütahya, 2010.

5. Kaya S. Sağlık Hizmetlerinde Kalitenin Ölçülmesi. Kaya S, editör. Sağlık Kurumlarında Kalite Yönetimi 1. Baskı. Eskişehir: Anadolu Üniversitesi; 2013. ss:60-89.

6. Aktan CC. Organizasyonlarda Toplam Kalite Yönetimi. Organizasyon ve Yönetim Bilimleri Dergisi 2012;4(2):235-262.

7. Ulaş S. Toplam Kalite Yönetiminde İnsan Kaynaklarının Rolü: Liderlik Üzerine Bir Uygulama. Türkiye Cumhuriyeti Merkez Bankası İnsan Kaynakları Genel Müdürlüğü, Ankara, 2002.

8. Lhor KN. Institute of Medicine; Committee to Design a Strategy for Quality Review and Assurance in Medicare. In: Lohr KN (ed.), Medicare: A Strategy for Guality Assurance. Volume 1. Washington, DC: National Academy Press; 1990. doi:https://doi.org/10.17226/1547.

9. Spath P. Introduction To Healthcare Quality Management. Health Administration Press and AUPHA Press. 2009.

10. Wolfe A. Institute of Medicine Report: Crossing the Quality Chasm: A New Health Care System for the 21st Century. Policy, Politics, \& Nursing Practice 2001;2(3):233-235. doi:10.1177/152715440100200312

11. Maxwell R J. Dimensions of quality revisited: from thought to action. Quality and Safety in Health Care 1992;1(3):171-177. doi:10.1136/ qshc.1.3.171

12. Erturgut R. Toplam Kalite Yönetimi ve Liderlik 1. Baskı. Ankara: Seçkin Yayıncllık; 2012.

13. Halis M. Toplam Kalite Yönetimi Perspektifinden İșletme Performansi “iş,Güç" Endüstri İlişkileri ve İnsan Kaynakları Dergisi 2007;9(4):4765.

14.ISO. Quality Management Principles. International Organization for Standardization. Genava, İsviçre, 2015. https://www.iso.org/iso/ pub100080.pdf adresinden erişildi.

15. Şimşek M. Toplam Kalite Yönetimi 5. Baskı. İstanbul: Alfa Yayınları; 2007. s:112-143.

16. Anderson JC, Rungtusanatham M. A theory of quality management underlying the Deming Management Method. Academy of Management Review 1994;19(3):472-509. doi:10.5465/AMR.1994.9412271808

17. Çolakoğlu MH. Kobi Rehberi. Cilt 1. Ankara: Türkiye Odalar ve Borsalar Birliği; 2002

18. Turaman C. Eski Törene Yeni Kllı: Kalite. Toplum ve Hekim Dergisi 1997;12(77):26-33.

19. Ercan i, Ediz B, Kan i. Hastaların Sosyo-Ekonomik Durumlarına Göre Sağlık Hizmetlerinden Memnuniyetlerinin İncelenmesi. İnönü Üniversitesi Tıp Fakültesi Dergisi 2004;11(3):161-167.

20. Doğanay P. Kaizen- Sürekli İyileștirme ile Hastanelerde İnsan Kaynaklarının Geliştirilmesi. Gazi Üniversitesi Sosyal Bilimler Enstitüsü, Yüksek Lisans Tezi, Ankara, 2008

21.Uzunçarşılı Ü, Toprak M, Ersun O. Şirket Kültürü ve iş Prensipleri. İstanbul: İstanbul Ticaret Odası; 2000. s:45-65.

22. Çetin C, Arslan ML, Dinç E. İnsan Kaynakları Yönetimi 3. Baskı. İstanbul: Beta Yayınları; 2004. s:67-75.

23.Levski Y. Augmented Reality and Healthcare: The Future is Now. https://appreal-vr.com/blog/augmented-reality-for-healthcare/ (Erisim Tarihi: 18 Ocak 2018).

24.Ziv A, Small SD, Wolpe PR. Patient Safety and Simulation-Based Medical Education. Medical Teacher 2000;22(5):489-495. doi:10.1080/01421590050110777

25. Baraz B. İnsan Kaynakları Yönetimi. Geylan R ve Tonus ZH, Editörler İnsan Kaynakları Yönetimi 1. Baskı. Eskişehir: Anadolu Üniversitesi Açıköğretim Fakültesi; 2013. s:84-110.

26. Uygun H. İnsan Kaynakları Yönetiminde Eğitim ve Geliştirme Faaliyetlerinin Çalışan Motivasyonuna Etkileri ve Sağlık Sektöründen Bir Vaka Analizi. İstanbul Gelișim Üniversitesi, Yüksek Lisans Tezi, İstanbul, 2015.

27. Tekkol İA, Demirel M. Öğretmen Adaylarının Öz-Yönetimli Öğrenme Becerilerine İlişkin Görüşlerinin İncelenmesi. Uluslararası Eğitim Prog ramları ve Öğretim Çalıșmaları Dergisi 2016;6(12):151-168.

28. Mesleki Eğitim Kanunu. 1983. http://www.mevzuat.gov.tr/MevzuatMetin/1.5.3308.pdf (Erișim Tarihi: 21.01.2018).

29. Şimşek MŞ, Öge HS. İnsan Kaynakları Yönetimi 4. Baskı. Konya: Eğitim Kitabevi; 2011. s:45-75

30. Özpulat F. Sağlık Bakanlığı Ankara Dışkapı Eğitim ve Araştırma Hastanesinde Çalıșmakta Olan Sağık Personelinin Hizmet İçi Eğitim Programına ilişkin Görüşlerinin Saptanması. Maltepe Üniversitesi Hemşirelik Bilim ve Sanat Dergisi, Sempozyum Özel SayıII, 2010

31. Ho W, Chang CS, Shih YL, Liang R. Effects of Job Rotation and Role Stress Among Nurses on Job Satisfaction and Organizational Commitment. BMC Health Serv Res. 2009;9(8):1-10. doi:10.1186/1472 6963-9-8.

32. Tutum C. Personel Yönetimi. Ankara: Türkiye ve Orta Doğu Amme İda resi Enstitüsü Yayınları; 1976. s:34-60.

33. Dikici MF, Yarıș F. Ondokuz Mayıs Üniversitesi Tıp Fakültesi Klinik Beceri Eğitiminde Standardize ve Simüle Hasta Programı. Türkiye Klinikleri Med Sci 2007;27;738-743.

34. Noe RA. İnsan Kaynaklarının Eğitimi ve Geliştirilmesi. C. Çetin, Çevir Editörü. 4. Baskı. İstanbul: Beta Yayınları; 2009. s:56-60.

35.Durmaz A. Hemşirelik Öğrencilerinin Ameliyat Öncesi ve Sonrası Hasta Bakım Yönetimini Öğrenmesinde Bilgisayar Destekli Simülasyon Tekniğinin Etkisi. Dokuz Eylül Üniversitesi Sağlık Bilimleri Enstitüsü, Doktora Tezi, İzmir, 2012.

36. Simulation Center.Florida Atlantic University - Charles E. Schmidt College of Medicine, 2013. http://med.fau.edu/sim/ (Erişim Tarihi: 21.01.2018)

37. Özsoy E. Stratejik İnsan Kaynakları Uygulamalarından Hizmet Içii Eğitim Faaliyetlerinin İşücü Devir Oranına Etkisi: Sağlık Sektöründe Bir Vaka Araştırması. Başkent Üniversitesi Sosyal Bilimler Enstitüsü, Yüksek Lisans Tezi, Ankara, 2017.

38.De Vinci KM. How Does Sensitivity Training Of Health Care Workers Impact Patient Satisfaction? Capella University, Doctoral Dissertations, 2010

39.Şenviren B. Hizmet İçi Eğitim Türleri Ve Sağlık Kurumlarında Hizmet İçi Eğitim. Beykent Üniversitesi, Yüksek Lisans Tezi, 2014.

40. Baykara ZG, Çalışkan N, Karadağ A. (2014). Vaka Analiz Yönteminin Hemșirelik Öğrencilerinin Etik Sorun Değerlendirme Becerilerine Etkisi. International Journal of Human Sciences 2014;11(1): 236-255 doi:10.14687/ijhs.v11i1.2769

41.Probleme Dayalı Öğrenim. Ankara Üniversitesi Tıp Fakültesi, 2015. http://www.medicine.ankara.edu.tr/2015/06/04/probleme-dayaliogrenim/ (Erisim Tarihi: 21.01.2018)

42. Kaptan F, Korkmaz H. Fen Egitiminde Probleme Dayalı Ögrenme Yak laşımı. Hacettepe Üniversitesi Eğitim Fakültesi Dergisi 2001;20:185192.

43. Yıldıım H. Probleme Dayalı Öğrenme Ve Proje Tabanlı Öğrenme Yöntemlerinin Illköğretim Öğrencilerinin Başarılarına Ve Tutumlarına Etkisi. Konya, Selçuk Üniversitesi Eğitim Bilimleri Enstitüsü, Yüksek Lisans Tezi, 2011.

44.Altınok M. Toplam Kalite Yönetimi İlkeleri Çerçevesinde İșletmelerde Eğitim İhtiyaçları Tespiti Ve Uygulamalı Bir Örnek. Balıkesir Üniversitesi Sosyal Bilimler Enstitüsü, Yüksek Lisans Tezi, Balıkesir, 2005

45. Senol Y, Yardım S, Bașarıcı İ. Öğrencilerin Standart Hasta Uygulaması Hakkındaki Görüşleri: Birinci Yıl Sonuçları. Tıp Eğitimi Dünyas 2014;41:19-26.

46. Sarıkoç G, Özcan C, Elçin M. Psikiyatri Hemşireliği Eğitiminde Standart Hasta Uygulamasının Öğrencilerin Klinik Uygulamalarına Etkisi: Öğrenci Görüşleri. Gülhane Tıp Dergisi 2016;58:404-410. doi:10.5455/gulhaกе. 223106

47. Dișcigil G, Dikici M, Yarıș F, Bașak O. Tıp Öğrencilerinin Klinik iletișim Becerilerinin Standardize Hastayla Değerlendirmesi İle ilgili Görüs ler. Turkiye Aile Hekimligi Dergisi 2009;13(1):23-26. doi:10.2399/ tahd.09.023

48. Walsh K. The Future of E-Learning in Healthcare Professional Education: Some Possible Directions. Ann Ist Super Sanità 2014;50(4):309310. doi:10.4415/ANN

49. Aktuna M. İnsan Kaynakları Yönetimi Eğitim Fonksiyonunun Örgütsel Güvene Etkileri ve Bir Uygulama. Dumlupınar Üniversitesi Sosyal Bilimler Enstitüsü, Yüksek Lisans Tezi, Kütahya, 2007.

50. Şahin ÖY, Saltan H, Alp AT, Özel B, Sanatçı S. Eğitimde Sanal Gerçeklik ve Arttırılmış Gerçeklik. 2016. https://www.kodyazar.net/tr/egitimde sanal-gerceklik-artirilmis-gerceklik/ (Erişim Tarihi: 30.09.2017).

51.Güler E. Mobil Sağılık Hizmetlerinde Oyunlaștırma. Açıöŏgretim Uygulamaları ve Araştırmaları Dergisi 2015;1(2):82-101. 
52. Taș D. Sağlık Hizmet Kalitesinin Ölçümüne ilișkin Bir Araștırma. Sağlıkta Performans ve Kalite Dergisi 2012;(4):79-102.

53. Eraslan N. "İstanbul İlindeki Kamu Özel Hastanelerde Kalite Yönetim Sisteminde Sürekli İyileştirme ( KAizEN)'nin , İnsan Kaynakları Yönetimi Üzerine Etkileri”, Okan Üniversitesi, Yuksek lisans tezi, 2014.

54. Hoş C. Sağlık Sektöründe Zoru Başarmak: Sağlık Sektöründe Akreditasyon. Süleyman Demirel Üniversitesi Sosyal Bilimler Enstitüsü Dergisi (CiEP Özel Sayısı), 2016;499-533.
Sakarya Tip Dergisi

2018;8(1):157-169

ALTINDiş ve Ark

Kalite Bağlamın

Sağllk Personeli Eğitimi 